MARMARA COĞRAFYA DERGISI SAYI: 33, OCAK - 2016, S.25-57

ISTANBUL - ISSN:1303-2429 E-ISSN 2147-7825 copyright @2016

http://www.marmaracografya.com

\title{
THE FLIPPED GEOGRAPHY LECTURE ${ }^{1}$ Flipped Classroom Modeli ile Üniversite Coğrafya Dersleri
}

\author{
Yrd. Doç. Dr. Merve Görkem ZEREN \\ Ondokuz Mayıs Üniversitesi, Eğitim Fakültesi, Coğrafya Ĕ̆itimi Anabilim Dalı, \\ mbilgi@omu.edu.tr
}

\begin{abstract}
The purposes of the study are to examine thoroughly the components that constitute individual perceptions of university students in geography major concerning benefits of the flipped classroom strategies (FC) and to facilitate their applicability through their own observations and suggestions. Sixty three female (47\%) and seventy-two male (53\%) university students in geography major $(n=135)$ participated in the research. Obtained data were analyzed both qualitatively (i. e. inductive analysis) and quantitatively (i. e. Chi-square test). According to the results: (1) Eight main conceptual categories based on the participants' observations concerning benefits of the FC, were identified. (2 Four main conceptual categories based on the participants' facilitative suggestions for the application of the FC, were identified. (3) Significant differences were not detected between the principal categories of observations and suggestions with regard to the participants' gender. The study concludes that the geography lecturers have an incredibly powerful tool to help university students come to terms with their misconceptions in the flipped environment. For the university students in geography major, flipping lectures promote independent learning, critical thinking, intrinsic motivation, probe understanding and allow much greater attention to the problem solving, maximise engagement through a variety of technology-facilitated strategies.
\end{abstract}

Keywords: flipped classroom; geography lectures, independent learning, intrinsic motivation, critical thinking

\section{$\ddot{O Z E T}$}

Bu araştırma, üniversite coğrafya bölümü öğrencilerinin, flipped classroom (FC) ögrenme modelinin kazanımlarına ve uygulanabilirliğinin kolaylaştırllmasına ilişkin düşüncelerini, kendi gözlem ve önerilerinden hareketle inceleme amacına yönelik olarak gerçekleştirilmiştir. Araştırmaya 63 'ü klz (\%47) ve 72'si erkek (\%53) olmak üzere toplam 135 üniversite coğrafya bölümü öğrencisi katılmıştır. Araştırma sonucunda elde edilen veriler

\footnotetext{
1 This paper was presented as an oral presentation at ISER 2015 World Conference on Education which was held in Yeditepe University, Istanbul between June 10-12, 2015.
} 
hem nitel (içerik analizi) hem de nicel (Chi-square) veri çözümleme teknikleri kullanılarak analiz edilmiştir. Araştırmanın bulgularına göre: (1) Üniversite coğrafya bölümü ögrencilerinin flipped classroom stratejilerinin önemli kazanımlarına ilişkin gözlemleri, bu gözlemlerin ortak özellikleri dikkate alınarak sekiz kavramsal kategori altında toplanmıştır. (2) Üniversite coğrafya bölümü ögrencilerinin FC stratejilerinin uygulanmasını kolaylaştırıcı önerileri, ortak özellikleri bakımından dört kategori altında toplanmıştır. (3) Katılımcıların öncelikli gözlem ve önerileri bir bütün olarak değerlendirildiğinde, üniversite coğrafya bölümü ögrrencilerinin cinsiyeti bakımindan önemli derecede farklllı görülmemiştir. Sonuç olarak, FC modelinin, üniversite ögrencilerinin kabul etmek istemedikleri yanlıs kanı ve önyargıları değiş̧tirmek konusunda, coğrafya eğitimcilerine önemli bilgiler sağlayan çok güçlü bir pedagojik araç olarak kullanılabileceği görülmüş̧ür. FC stratejilerinin uygulanmastyla kurulan etkileşimli ögrrenme yaşantıları aracılı̆̆ı ile üniversite coğrafya bölümü ögrencilerinin, birbirlerinin öğrenmesine yardım ederek bağımsı öğrenme ve sorular sorarak bilgi inşa etme ve kavrama yeteneklerinin derinleştiği, derse yönelik içsel motivasyonlarının yükseldiği görülmüştür.

Anahtar Kelimeler: Çevrilmiş ögrrenme modeli, üniversite coğrafya dersleri, içsel motivasyon, bağımsız ögrenme, eleştirel düşünme

\section{INTRODUCTION}

Flipped classroom is a recently popularised learning model although it has taken a part in literature since 2000. Also called flipped classroom, inverted classroom, backwards classroom and switched classroom in international literature (Baker, 2000; Lage et al. 2000; Frederickson et al. 2005; Gannod et al. 2008; Zappe et al. 2009; Fulton, 2012; Bergman \& Sams, 2012; Brown, 2012; Pierce \& Fox, 2012; Strayer, 2012; Herreid \& Schiller, 2013; Conner et al. 2014; Yeung \& O'Malley, 2014;), the learning model may be seen to be translated in Turkish as çevrilmiş ögrenme modeli, evde ders okulda ödev modeli and dönüşı̈̈rülmüş ögrenme modeli (Demiralay ve Karataş, 2014; Sever, 2014).

The increased popularity of Flipped Classroom model in recent years is a reaction to the fact that conventional teaching lacks the efficiency to educate the human resources that the time requires. Although the contemporary objectives are set, it is impossible to accomplish these objectives by means of conventional methods. Students 
graduate with no depth knowledge in conventional methods, in which they are not provided either with activities that make them think and encourage them to investigate or with opportunities to use knowledge, solve problems and reconstruct knowledge. Individuals who are lack of abilities to think effectively, solve problems and investigate can't produce suitable solutions when they encounter a confusing situation in their future lives (Açıkgöz, 2007; Lancaster, 2013).

The criticisms that conventional methods employed in classrooms where everything is determined, presented and controlled by the teacher fade the innate desire of students to know-understand, passivize them and hinder their thinking abilities have given acceleration to putting into practice such implementations forming the basis of flipped classroom model as not conveying readily available knowledge, students' assuming responsibility for their own learning processes, launching and leading the efforts to gain knowledge by themselves.

Flipped classroom is a learning model which suggest that students should examine lecture contents shared on social network platform prepared by teachers, watch videos, read articles and think about the quiz questions related to the contents shared in the light of their prior knowledge, and come to the classroom, where the topic will be discussed in detail, well prepared (Tucker, 2012; Vaughan, 2014). The intellectual development of the model is explained by stressing the necessity of conveying the materials prepared for the lecture electronically (Baker, 2000; Milman, 2012). When the model is implemented, the time the teacher would spend for the presentation of lecture content can be used for enriched learning activities. The model promotes the flexibility offered by electronically learning platforms in terms of its application and the quality of face to face education along with the social interaction offered by the classroom environment (Brown, 2012; Mull, 2012; LaFee, 2013). Arriving at the classroom with preliminary preparation, the students take an active part in the activities the lecturer has prepared. Lecturer begins the lesson by determining whether the students have made preparations for the content shared for the lesson, then enables the students to share their ideas about the topic, ask questions, discuss, evaluate and designs activities in which what has been learned about the shared content can be practised (Luntley, 2009; McKnight et al., 2013). 
In the studies in which the effect of flipped classroom model on students' academic performance, participation in the lesson, motivation and attitudes at primary, secondary and higher education levels (Wilson \& Gerber, 2008; Papadapulos \& Roman, 2010; Sadaghiani, 2012; Steed, 2012; Bishop \& Verleger, 2013; Fulton, 2013; Gaughan, 2014), it is stated that the interaction in the classroom and the interest of the students increased when they were given instructions which clearly states the transactions and objectives in the implementation phase of the strategies.

\subsection{Framework of the Flipped Classroom}

Framework of the flipped classroom model is based on constructivism and cognitive learning theory (Handwerker, 2012). These theories emphasise the importance of constructing information during the learning process, but they don't mention what opportunities the learner should be given in order to construct the information and what the teacher should concretely do. Synthesising constructivist and cognitive learning theories, and the educational studies on how they are put into practice in various phases from designing the lesson to its implementation have become a distinctive field of study (Açıkgöz, 2014). Flipped classroom, the basic views of which advocate active learning, is of significant importance in terms of being a model which is increasingly attracting attention as a result of these efforts.

In the constructivist theory, it is believed that knowledge is a construction formed by the learner and prior knowledge has an important place in this process; for this reason these constructions is peculiar to the individual. Thus, it is impossible for an individual to convey the constructions he formed for himself to another one. In other words, the lecturer can't transfer the knowledge, concepts and thoughts into students' minds. Even if he tries to do so, the students can't fully acquire what the lecturer has told. The things told by the teacher are interpreted and transformed by students. This is the reason why students don't learn the exact things teachers try to teach them in the same way as they planned (Açıkgöz, 2007; Wallace et al., 2014). These explanations offered by constructivism about learning process compose the teacher's role as a facilitator in the process in which students construct knowledge by intervening between the students and the teaching programme. The lecturer in flipped classroom model is not the wise man who dictates the 
topic from his chair, but a guide who supervises his students where necessary, diversifies teaching actions, facilitates their learning by observing their development. Faculty are not the "sage on the stage", but instead collaborate with students to ensure mastery of essential course concepts (King, 1993).

Cognitivism, a variation of constructivism in learning field, composes the theoretical framework of basic views on which flipped classroom activities are based on in terms of its interest in the mental side of learning. Cognitivists try to explain the structure of knowledge, how it is obtained, perceived, remembered and how it should be used in solving problems. According to cognitivists, learning is a process in which the learner is not passive but active. Cognitivists argue that students are not passivized receivers to whom knowledge is transmitted; on the contrary, they process knowledge in a peculiar active way. Students add newly heard and seen things to their previous knowledge. They process knowledge rather than memorise it by organising, categorising, testing, sampling and interpreting it, and reconstruct it. The natural learning happening in the end is affected by the students' former learnings and the way in which they process knowledge. The aim of education should be natural knowledge; it should be a whole composed of what has been learned in relation with each other (Caine \& Caine, 1991; Collins, 2006; Svinicki, 2004; Açıkgöz, 2014). While students in traditional classrooms are made too passivized to assume the responsibility for their own learning, those in flipped classrooms lead the learning process themselves (Bruff, 2009; Goodwin \& Miller, 2013). In traditional teaching, students are generally lonely; as there is hardly any social interaction, they may not find anyone to listen to them when they would like to ask a question or tell their thoughts. By contrast, in flipped classroom practices the learning process is shared in a social environment (Roehl et al., 2013; Hawks, 2014). Even the most passivized students are able to take active part in knowledge acquisition activities. Everyone can ask questions and explain their ideas.

In flipped Potential in Turkey 31 (23.0\%); students that attented the lecture of Geography of the Middle Part of the Black Sea $37(27,4)$ and students that attented the lecture of Climate Changes and their Environmental Effects 28 (\% 20,7). Participants are located in 44 students $(\% 32,6)$ from second grade of geography major, 45 students (\% 
33,3) in third grade and 46 students $(\% 34,1)$ in fourth grade.

The lecture of Environmental Management is offered for the third grade students of geography major in 2 theoretical hours a week; the lecture of Rural Potential in Turkey and the lecture of Climate Changes and their Environmental Effects are offered for the fourth grade students of geography major in 2 theoretical hours a week; and the lecture of Geography of the Middle Part of the Black Sea is offered for the second grade students of geography major in 2 theoretical hours a week.

In accordance with preliminary preparations for the lecture, the students were informed of flipped classroom practices and information packages of the lecture including PowerPoint presentations, photos, articles, videos, website links, objectives and bibliographic resources along with short exams related to the lecture content were shared with the students electronically a week before the lecture. The students were asked to participate in the lecture by considering the solutions to the questions of the short exams and preparing extra questions (Appendix 1).

The lectures were launched in a way in which the students discussed the solutions to the questions of the short exams and those which they themselves had prepared, presented additional examples, explained them and compared them to other examples; cognitive and metacognitive inquiring strategies were employed, which necessitates effective thinking and facilitates learning; the spread of conflicts were prevented by helping the solution to the conflicts emerged from time to time. The issues that the students didn't understand or would like further information were clarified, and efforts were made to determine the reasons for such information gaps. The students were evaluated on a daily basis in the lecture of teaching-learning processes in accordance with their active participation performances in the activities at the end of the lecture.

The purposes of the study are to examine thoroughly the components to form of individual perceptions of university students in geography major concerning benefits of the FC and to facilitate their applicability through their own observations and suggestions. This study is of significant importance in terms of being one of the first studies which discuss FC practices by putting them into reality in geography 
education field, which will make a contribution to Turkish literature. Specifically, the following parameters guided this study:

1. What benefits of the FC as teaching strategies according to university students in geography major?

2. What facilitative suggestions for the application of the FC as teaching strategies according to university students in geography major?

3. What conceptual categories can be derived from the observations and suggestions of university students in geography major concerning acquisitions of the FC?

4. How do the principal conceptual categories differ across participants' gender?

\subsection{Data Collection and Analysis Processes}

It is a descriptive study carried out in a survey model to examine the thoughts of university students at geography major about easing the applicability of FC learning model and its benefits in the lights of their own observations and suggestions.

The participants for this study included a total of 135 university students enrolled geography programme in the Faculty of Science and Literature of Ondokuz Mayis University. The proportional division of gender was as follows: Sixty-three females (47\%) and seventy-two males $(53 \%)$. Of the students who participated in the lectures where flipped classroom strategies are employed, the percentages of those who were included in the study group of the research are: 39 (28,9\%) in Environmental Management; 31 (23,0\%) in Rural Potential in Turkey, 37 $(27,4 \%)$ in Geography of the Middle Part of the Black Sea, $28(20,7 \%)$ in Climate Change and their Environmental Effects. 44 students $(32,6 \%)$ from the second grade of geography major, 45 students $(33,3 \%)$ from the third grade and 46 students $(34,1 \%)$ from the fourth grade composed the study group of the research.

In this study, research parameters were designed in the first stage to analyse the observations and suggestions of university students in geography major concerning FC. In the second stage, research 
parameters were configured and were converted into observationoriented and open pointed questions. And in the third stage, pilot administration $(\mathrm{n}=100)$ was conducted using conversation strategy, instrumentation experts $(\mathrm{n}=8)$ review the open pointed research questions to establish content and face validity. Some modifications were made according to the recommendations made by these experts. The university students in geography major were asked to write a composition about contributions of the FC through their own observations and facilitative suggestions for the application of FC. The participants were given one class-hour (roughly 45 minutes) to write their impressions using own handwritings. The compositions of participants that were the main data sources of this research were analyzed qualitatively and the categories of observation and suggestion were constituted concerning FC.

The observations of participants were categorized considering their impressions concerning FC and 8 categories were constituted: (1) Promotes independent learning, (2) gives multifaceted perspective, (3) allows much greater attention to problem solving, (4) maximises engagement, (5) relieves the exam anxiety, (6) assesses students for knowledge gaps frequently in lectures, (7) identifies student performance, (8) probes understanding. For data coding, the observation categories were given $1,2,3,4,5,6,7,8$ respectively. It was determined that according to the specialists $(n=8)$ in assessment instruments and in the field the designed open ended questions are expedient in terms of their content and face validity. All the compositions written by 135 participants were evaluated for this study.

The suggestions of participants concerning FC were categorized and 4 categories were constituted: (1) Various activities should be implemented, (2) The FC online work should not replace direct interaction, (3) quizzes should be applied at the end of the lesson (4) all students should have access to technology. For data coding, the suggestion categories were given 1,2,3,4 respectively and transferred into SPSS statistical programme.

Our procedure for analyzing the observations and the suggestions encompassed the following stages: (1) Naming stage, (2) sorting stage, (3) organization stage, (4) categorization stage, (5) establishing reliability 
and validity, (6) analyzing the data quantitatively with SPSS (Statistical Package for the Social Sciences).

1. Naming stage: In the first stage we simply coded the names of observations and suggestions ("promotes independent learninig", "gives multifaceted perspective", etc.).

2. Classification stage: In the second stage, we went through the raw data again and analyzed each observation and suggestion to characterize its elements. By using this approach, we were able to break down the suggestions and the observations into analyzable parts, looking for salient features, common elements and similarities.

3. Organization stage: In this stage, we revised the compositions of participants in three times and reviewed the raw to choose a sample expression for each suggestion and observation.

4. Categorization stage: In the fourth stage, 8 main conceptual categories based on the participants' observations concerning the acquisitions of FC were identified. Moreover, 4 main conceptual categories based on the participants' facilitative suggestions for the application of FC were identified. During this stage, we coded each category title.

5. Establishing inter-rater reliability rate: Detailed reporting the study data and clarifying the results are important criteria for validity in a qualitative research (Yıldırım \& Şimşek, 2013, p. 75). In this research, we asked two outside researchers to independently sort the 135 observations into the 8 categories. We then asked each coder to read each observation expression and place it in one of the 8 conceptual categories the specific observation could fall into. To estimate the inter-rater reliability rate, we used Miles and Huberman's (1994, p. 48) Formula (i.e., Reliability $=$ Agreement / Agreement + Disagreement). Accordingly, the 135 observations were classified by the two independent coders and the level of agreement between their individual ratings and ours was 1 and .99, respectively. Miles and Huberman (1994, p. 62) suggest that the final inter-coder agreement rate in qualitative data analysis should approach or exceed $90 \%$. In our study, one coder identified 8 main conceptual categories based on the participations' observations concerning acquisitions of fieldworks (1. Promotes critical thinking, 2. 
Helps student come to terms with their misconceptions, 3. Provides opportunities for research and inquiry, 4. Increases motivation, 5. Provides flexible and optional plans, 6. Probes understanding, 7. Assesses students frequently for knowledge gaps, 8. Permanent labeling is not done) - i.e.,reliability: $362 / 362=1$. The second coder identified 8 main conceptual categories but put forward the independent learning process instead of deep learning process - i.e., reliability: 362/362+1= .99 .

6. Quantitative data analysis with SPSS: In the last stage, we entered the study data into the SPSS package program to calculate frequencies (f) and percentages (\%) of the observations and suggestions as well as to compare our dominant categories across the participants' gender (Pearson Chi-square tests) (Büyüköztürk, 2005, p. 42).

In the strategy employed to ensure the internal reliability, specialists were consulted to see whether the observations under the eights conceptual categories which were developed in the study represented the conceptual categories in question and whether the suggestions assembled under four categories reflected similar suggestions for easing the implementation of FC practices. In line with this purpose, two academic members employed in the same faculty were asked to match the observations of 135 participants with conceptual categories and to categorise the participants' suggestions according to their common features. Then, the matching and categorisation made by the specialists were compared with the researchers' own matching and categorisation. By determining the number of agreement and disagreement in the evaluations of the specialists and the researchers, the internal reliability of the study was calculated by means of the formula $(1994$, p. 64) of Miles and Huberman (Reliability = Agreement/Agreement+Disagreement). According to Miles and Huberman (1994), where the conformity between the evaluations of the specialists and the researchers reaches or exceeds $90 \%$, a desirable reliability is obtained. In calculation of the reliability regarding the conceptual observation categories in this study, the reliability was found in percentages of $100 \%$ and $99 \%$ respectively. In the lights of the observation expressions, one of the specialist classified the participants' observations under eight conceptual categories in terms of their features in common with the gains of flipped classroom strategies: improve 
critical thinking, help change wrong opinions and prejudices, provide the opportunity to research and inquire, promote the motivation for the lesson, the plans are flexible and interchangeable, the subject is learned quickly within the lesson, information gaps are filled on daily basis, low performance is not labelled. So, it is seen that the conformity in the evaluations of the first specialist and researcher is $100 \%$.

The other specialist classified the participants' observations under eight conceptual categories, but he used the expression "students take more risks" rather than "independent learning is supported": Students take more risks; students are motivated to listen to each other; encourage thinking, increase the expectation from the lesson, the decisions are made with the students, make it possible to learn in a short time, the performance is evaluated during the lesson and wrong answers are not underestimated. So, calculation of the reliability $=362 / 362+1=.99$. It is also seen that the agreement on the evaluations of the specialists and the researcher regarding suggestion categorisation provides a desirable level of reliability $(100 \%)$. Both of the specialists categorised the participants' suggestions under six headings in line with the researcher: It is important that all the students should be provided with access to technological aids, telling the subject through presentation method shouldn't end completely, the activities could be enriched and various teaching methods could be employed by taking the students' learning styles into account so that it will appeal to each of them, short exams could be carried out at the end of the lesson. These results indicate that this study has reached a desirable level of reliability.

Subtitles should be in lower case and suitable to the mentioned format. Other sub-sections need to follow the same format.

\section{FINDINGS}

In this part, the frequency distribution of the answers to the study questions as well as the profiles of the study group is mentioned (Table 1 ); eight conceptual observation categories and four suggestion categories are made known and outstanding samples of observations and suggestions are presented. Whether the differences observed among the participants who compose the sample are meaningful statistically according to the observation categories regarding the benefits of FC strategies was tested by means of Chi-Square test for one sample. 
Whether the differences observed among the participants are meaningful statistically according to the suggestion categories about easing the applicability of FC strategies was again tested by means of Chi-Square test for one sample. Also, whether there is a meaningful difference between the participants' gender and their observations regarding FC strategies was tested by means of Chi-Square test for two variables. Whether there is a meaningful difference between the participants' gender and their suggestions regarding FC strategies was again tested by means of Chi-Square test for two variables.

\begin{tabular}{|l|}
\hline \multicolumn{2}{|c|}{ Table 1: Frequency distribution of the suggestions and benefits related to the } \\
FC strategies and sample profile
\end{tabular}

Whether there is a meaningful difference between the participants' gender and their observations regarding the gains of FC strategies was tested by means of Chi-Square test for two variables. (Table 2). This technique is used to test whether there is a meaningful difference two categorical variables. The relation between two variables indicates that the answers at one variable's level change at other variables' levels. Chi-Square test inquires whether there is a meaningful difference between the numbers-values observed in the cells which are formed according to the levels of two categorical variables (number of lines x number of columns) and expected numbers-values. Accordingly, as the difference between these two values increases, so does the 
possibility that the relation between the variables is meaningful (Büyüköztürk, 2014, p. 148).

\begin{tabular}{|l|l|c|c|c|c|}
\hline \multicolumn{7}{|c|}{ Table 2: Frequency distribution of the suggestions and benefits related to the } \\
& $\begin{array}{l}\text { FC strategies and sample profile } \\
\text { Maximises } \\
\text { engagement }\end{array}$ & $\begin{array}{c}\text { Probes } \\
\text { understanding }\end{array}$ & $\begin{array}{c}\text { Gives } \\
\text { multifaceted } \\
\text { perspective }\end{array}$ & $\begin{array}{c}\text { Promotes } \\
\text { independent } \\
\text { learning }\end{array}$ & $\begin{array}{c}\text { Allows much } \\
\text { greater } \\
\text { attention } \\
\text { to problem } \\
\text { solving }\end{array}$ \\
\hline Female N & 8 & 3 & 15 & 14 & 10 \\
\% & 12.7 & 4.8 & 23.8 & 22.2 & 15.9 \\
\hline Male N & 12 & 5 & 9 & 18 & 13 \\
$\mathbf{\%}$ & 16.7 & 6.9 & 12.5 & 25.0 & 18.1 \\
\hline Total & 20 & 8 & 24 & 32 & 23 \\
N \% & 14.8 & 5.9 & 17.8 & 23.7 & 17.0 \\
\hline
\end{tabular}

\begin{tabular}{|l|c|c|c|c|}
\hline \multicolumn{5}{|c|}{ Table 3: Frequency distribution of the suggestions and benefits related to the } \\
FC strategies and sample profile \\
\hline & $\begin{array}{c}\text { Identifies } \\
\text { student performance }\end{array}$ & $\begin{array}{c}\text { Assesses students } \\
\text { for knowledge gaps } \\
\text { frequently in lectures }\end{array}$ & $\begin{array}{c}\text { Relieves the exam } \\
\text { anxiety }\end{array}$ & Total \\
\hline Female N & 6 & 2 & 5 & 63 \\
\% & 9.5 & 3.2 & 7.9 & 100.0 \\
\hline Male N & 2 & 6 & 7 & 72 \\
\% & 2.8 & 8.3 & 9.7 & 100.0 \\
\hline Total & 8 & 8 & 12 & 135 \\
N \% & 5.9 & 5.9 & 8.9 & 100.0 \\
\hline
\end{tabular}

According to the result of $\chi 2$ test for the two variables illustrated in Table 2 and Table 3, it is seen the percentage of those who think the most important benefit of FC strategies is that "maximises engagement" is $12,7 \%$ among the female students while it increased to $16,7 \%$ among the male students. It is seen the percentage of those who think the most important benefits of FC strategies is that "probes understanding" is $4,8 \%$ among the female students while it increased to $6,9 \%$ among the male students. It is seen the percentage of those who think the most important benefit of FC strategies is that "gives multifaceted perspective" is $23,8 \%$ among the female students while it decreased to $12,5 \%$ among the male students. It is seen the percentage of those who think the most important benefit of FC strategies is that "promotes independent learning" is 22,2\% among the female students while it is $25 \%$ among the male students. It is seen the percentage of those who think the most important benefit of FC strategies is that "allows much greater attention to problem solving" is $15,9 \%$ among the female students while it is $18,1 \%$ among the male 
students. It is seen the percentage of those who think the most important benefit of FC strategies is that "identifies student performance" is $9,5 \%$ among the female students while it decreased to $2,8 \%$ among the male students. It is seen the percentage of those who think the most important benefit of FC strategies is that "assesses students for knowledge gaps frequently in lectures" is $3,2 \%$ among the female students while it increased to $8,3 \%$ among the male students. It is seen the percentage of those who think the most important benefit of FC strategies is that "relieves the exam anxiety" is 7,9\% among the female students while it increased to 9,7\% among the male students. Accordingly, the female and male participants brought to the fore as the most important benefit of the FC strategies that "promotes independent learning". There is no meaningful relation between the participants' gender and their observations about the benefits of flipped classroom strategies $\left[\chi^{2}(7)=\right.$ $7,45 \mathrm{p}>0.05]$.

\begin{tabular}{|l|c|c|c|c|c|}
\hline \multicolumn{6}{|c|}{ Table 4: Suggestions to facilitate the FC strategies according to the gender of } \\
the participants and Chi-square test $(\chi 2)$ results \\
\hline $\begin{array}{c}\text { Various activities } \\
\text { should be } \\
\text { implemented }\end{array}$ & $\begin{array}{c}\text { The FC } \\
\text { online } \\
\text { work should } \\
\text { not } \\
\text { replace } \\
\text { direct } \\
\text { interaction }\end{array}$ & $\begin{array}{c}\text { Quizzes should } \\
\text { be applied at the } \\
\text { end of the lesson }\end{array}$ & $\begin{array}{c}\text { All students should } \\
\text { have access to } \\
\text { technology }\end{array}$ & Total \\
\hline $\begin{array}{l}\text { Female } \\
\text { N }\end{array}$ & 28 & 24 & 7 & 4 & 63 \\
\hline Male N & 44.4 & 38.1 & 11.1 & 6.3 & 100.0 \\
\% & 28 & 26 & 11 & 7 & 72 \\
\hline $\begin{array}{l}\text { Total } \\
\text { N \% }\end{array}$ & 38.9 & 36.1 & 15.3 & 11 & 135 \\
\hline
\end{tabular}

According to the result of $\chi 2$ test for the two variables illustrated in Table 4, it is seen the percentage of those who think that "various activities should be implemented" is a facilitative suggestion in the implementation of FC strategies is $44,4 \%$ among the female students while it decreased to $38,9 \%$ among the male students. It is seen the percentage of those who think that "the FC online work should not replace direct interaction" is a facilitative suggestion in the implementation of FC strategies is $38,1 \%$ among the female students while it decreased to $36,1 \%$ among the male students. It is seen the percentage of those who think that "quizzes should be applied at the end 
of the lesson" is a facilitative suggestion in the implementation of FC strategies is $11,1 \%$ among the female students while it increased to $15,3 \%$ among the male students. It is seen the percentage of those who think that "All the students should have access to technology" is a facilitative suggestion in the implementation of FC strategies is 6,3\% among the female students while it is $9,7 \%$ among the male students. Thus, it is seen that the female and male participants give prominence to the suggestion that it will be easier to implement FC strategies as a learning model if the activities are enriched by taking the students learning styles into account so as to appeal to all students and distinctive teaching methods are integrated in them. There is no meaningful relation between the participants' gender and their suggestions about easing the implementation of flipped classroom strategies $\left[\chi^{2}(3)=1,19 p>0.05\right]$. According to the test results, the gender of the participants doesn't affect their opinions about the gains of flipped classroom strategies and their suggestions about easing the strategies.

\subsection{General Findings}

1. Participants identified a total of 8 well-articulated conceptual categories based on their own observations concerning the benefits of FC. The conceptual categories based on participants' observations include the following: (1) Promotes independent learning (32\%), (2) Gives multifaceted perspective (24\%), (3) Allows much greater attention to problem solving (23\%), (4) Maximises engagement (20\%), (5) Relieves the exam anxiety (12\%), (6) Assesses students for knowledge gaps frequently in lectures $(8 \%)$, (7) Identifies student performance (8\%), (8) Probes understanding (8\%).

2. Four main conceptual categories based on the participants' facilitative suggestions for the application of FC, were identified. The suggestions of students concerning FC include the following: (1) Various activities should be implemented (56\%), (2) The FC online work should not replace direct interaction (50\%), (3) quizzes should be applied at the end of the lesson (18\%), (4) all students should have access to technology (11\%). 
3. Significant differences were not detected between the principal categories of observations and suggestions with regard to the participants' gender.

\subsubsection{Main conceptual observation categories}

Chi-Square test is a good-conformance test for a single sample to examine whether the individuals or objects in the levels of a categorical variable show a meaningful difference. The test examines the meaningfulness in the difference between the numbers observed in each category of the variable and the expected numbers for the categories. Chi-Square test for one sample can be used in experimental or scanning studies where variability in regard to a single variable in studies with one group is examined (Büyüköztürk, 2005, p. 145).

Whether there is a meaningful difference among the observation categories of the participants regarding the benefits of FC strategies was examined through Chi-Square test for one sample (Table 4). The participants' observations about the benefits of FC strategies were categorised under eight headings: Promotes independent learning, gives multifaceted perspective, allows much greater attention to problem solving, maximises engagement, relieves the exam anxiety, assesses students for knowledge gaps frequently in lectures, identifies student performance and probes understanding.

\begin{tabular}{|l|c|c|c|}
\hline \multicolumn{5}{|c|}{$\begin{array}{l}\text { Table 5: Chi-square test ( } \chi 2) \\
\text { observations according to observation categories relating to the benefits of } \\
\text { participants }\end{array}$} \\
\hline Observations & Observed N & Expected N & Residual N \\
\hline Promotes independent learning & 32 & 16.9 & 15.1 \\
\hline Gives multifaceted perspective & 24 & 16.9 & 7.1 \\
\hline $\begin{array}{l}\text { Allows much greater attention to } \\
\text { problem solving }\end{array}$ & 23 & 16.9 & 6.1 \\
\hline Maximises engagement & 20 & 16.9 & 3.1 \\
\hline Relieves the exam anxiety & 12 & 16.9 & -4.9 \\
\hline $\begin{array}{l}\text { Assesses students for knowledge } \\
\text { gaps frequently in lectures }\end{array}$ & 8 & 16.9 & -8.9 \\
\hline Identifies student performance & 8 & 16.9 & -8.9 \\
\hline Probes understanding & 8 & 16.9 & -8.9 \\
\hline Total & 135 & & \\
\hline
\end{tabular}


According to the result of $\chi^{2}$ test for one sample illustrated in Table 5, the difference seen among the participants' observation categories about the benefits of FC strategies was found to be meaningful $[\chi 2(7)=34,77 p<0.001]$. It is seen that of all the participants, 32 give prominence to the benefit that "promotes independent learning", 24 to "gives multifaceted perspective", 23 to "allows much greater attention to problem solving", 20 to "maximises engagement", 12 to "relieves the exam anxiety", 8 to "assesses students for knowledge gaps frequently in lectures", 8 to "identifies student performance", 8 to "probes understanding". These findings indicate that the benefit "promotes independent learning" and "gives multifaceted perspective" are considered to be the most important benefits of FC strategies.

Category 1: Promotes Independent Learning: It appears from the data that this category was identified by 14 female university students in geography major (22.2\%) and 18 male student teachers $(25.0 \%)$.

Observation samples brought to the fore as the most important contribution of the FC strategies that "promotes independent learning" are as follows:

"I used to be a student who panicked and tried to answer immediately when I was asked any question. However, in lectures that use FC strategies, in which more attention is paid to the dialogue and listening, I learned that I should listen first, perceive the questions asked and then make comments on them. I have developed self-confidence." (F 29)

"We have learned through the implementation of these strategies that thinking is much more important than whether the idea is right or wrong. Everyone's opinion is respected. I think the lectures in which we can express our thoughts without being under the influence of any idea taking risk even if they are inaccurate or incomplete are more enjoyable and instructive." (F 16)

"To me, the most important benefit of FC strategies for us is that it helps to increase our self-confidence. If we think our class as a stage, while we were just spectators in other lectures, we were actors in the lectures using FC strategies. We participated actively in the lecture, that is to say, we wrote the scenario, we directed it and we played it. I think using these strategies increases the efficiency of the lectures. Because we're right in the center of the lecture." (M 101)

Category 2: Gives Multifaceted Perspective: There are 15 female participants $(23.8 \%)$ and 9 male participants $(12.5 \%)$ under this category. 
Observation samples brought to the fore as the most important contribution of the FC strategies that "gives multifaceted perspective" are as follows:

\begin{abstract}
"I think there has been a considerable reduction in the number of false beliefs which I thought to be right now that I have had the chance to ask the questions in my mind during the lectures in which FC strategies are used. Differences of opinion and even conflicts can arise in lectures; different questions are asked, different items of information are shared. These differences deepen my perspective and teaches a lot more. I realized that I can understand more easily the information transmitted verbally by my friends compared to reading from a book." (F 26)

"Our lecturer encouraged us to listen to our friends responses respectfully to make a judgement about their ideas, she follows discussions and helps to solve the conflicts by asking questions and gives examples when neccessary and makes assessments to keep the discussions within their limitations. Briefly, each student contributes to learning under the guidance of our lecturer." (F 44)
\end{abstract}

\title{
Category 3: Allows Much Greater Attention to Problem
} Solving: Category 3 was identified by 10 female participants $(15.9 \%)$ and 13 male participants (18.1\%).

Observation sample brought to the fore as the most important contribution of the FC strategies that "allows much greater attention to problem solving" is as follows:

"We talked more about the options by brainstorming in the lecture to answer the question about which the topics we did not understand; we thought more, we did more research, we gathered more information and we prepared proposals more easily." (M 14)

Category 4: Maximises Engagement: This category was identified by 18 female participants $(12.7 \%)$ and 12 male participants $(16.7 \%)$.

Observation sample brought to the fore as the most important contribution of the FC strategies that "maximises engagement" is as follows:

\footnotetext{
"Instead of listening to a routine power point presentation throughout the lesson, starting the class discussion in which we can share different thoughts maximized engagement and attention, lecture information pack and materials sent before the lecture arouse curiosity." (F 8)
}

Category 5: Relieves the Exam Anxiety: This category was identified by 5 female participants (7.9\%) and 7 male participants $(9.7 \%)$. 
Observation sample brought to the fore as the most important contribution of the FC strategies that "relieves the exam anxiety" is as follows:

"Preparing lengthy lecture notes and working alone are really boring. FC was a learning model which made easy for me to practice what I learned during the semester in real life. This model has enabled me to understand the whole issue in a short time. I did some research before coming to the class. While preparing for the exam, it was sufficient just to look through the lecture materials. Because I was active in the lecture, and what I learned was permanent. I didn't spend much time preparing for the exam." (F 31)

Category 6: Assesses Students for Knowledge Gaps Frequently in Lectures: This category was identified by 2 female participants $(3.2 \%)$ and 6 male participants $(8.3 \%)$.

Observation sample brought to the fore as the most important contribution of the FC strategies that "assesses students for knowledge gaps frequently in lectures" is as follows:

"In FC applications, instruction done by considering the questions we prepared provides us with the opportunity to give immediate feedback regarding our answers. The lecturer gives individual scores evaluating our responses in lectures; these points are added to the score that we get in classic written examinations. These scores are added to our performance grade throughout the semester at a certain rate." (M 62)

Category 7: Identifies Student Performance: This category was identified by 6 female participants $(9.5 \%)$ and 2 male participants $(2.8 \%)$.

Observation sample brought to the fore as the most important contribution of the FC strategies that "identifies student performance" is as follows:

\footnotetext{
"When our answers to the questions posed in the classroom are wrong, it is not said directly that they are wrong. Instead, we are made to guess why the answer might be wrong and we are expected to think again about it. Our lecturer asks the same question in a different way and wants us do reflect on it again. This kind of learning strategy encourages the reluctant students." ( M 118)
}

Category 8: Probes Understanding: This category was identified by 3 female participants (4.8\%) and 5 male participants (6.9\%).

Observation sample brought to the fore as the most important contribution of the FC strategies that "probes understanding" is as follows:

"This learning model made us become familiar with new practices. It also taught us how to think, do reseaches, probe understanding, establish a connection between our present and prior knowledge, exemplify and make comparisons and learn together." (M 64) 


\subsubsection{Main conceptual suggestion categories}

In the study, whether there is a meaningful difference among the participants' suggestion categories about facilitating the implementation of FC strategies was examined through Chi-Square test for one sample (Table 5). The participants' suggestions to facilitate the implementation of flipped classroom strategies were categorised under four headings: "Various activities should be implemented, the FC online work should not replace direct interaction, quizzes should be applied at the end of the lesson and all students should have access to technology".

According to the result of $\chi^{2}$ test for one sample illustrated in Table 6, it was seen that of all the participants, 56 of them suggest about facilitating the implementation of flipped classroom strategies that various activities should be implemented; 50 of them suggested the FC online work should not replace direct interaction; 18 of them suggested quizzes should be applied at the end of the lesson; 11 of them suggested all the students should have access to technology. These findings show that the outstanding suggestions to facilitate the implementation of FC strategies are "distinctive methods should be integrated into the practices by taking the learning styles into account" and " lecturing shouldn't be ended completely by means of presentation". The difference observed among the facilitative suggestion categories of the participants for the implementation of flipped classroom strategies was found to be meaningful $\left[\chi^{2}(3)=45,17 \mathrm{p}<0.001\right]$.

\begin{tabular}{|l|c|c|c|}
\hline \multicolumn{5}{|c|}{$\begin{array}{c}\text { Table 6: Chi-square test }(\chi 2) \text { results on the comparison of the frequency of } \\
\text { suggestions according to suggestion categories of participants }\end{array}$} \\
\hline Suggestions & Observed N & Expected N & Residual N \\
\hline $\begin{array}{l}\text { Various activities should be } \\
\text { implemented }\end{array}$ & 56 & 33.8 & -22.8 \\
\hline $\begin{array}{l}\text { The FC online work sholud not replace } \\
\text { direct interaction }\end{array}$ & 50 & 33.8 & 16.3 \\
\hline $\begin{array}{l}\text { Quizzes should be applied at the end } \\
\text { of the lesson }\end{array}$ & 18 & 33.8 & -15.8 \\
\hline $\begin{array}{l}\text { All students should have access to } \\
\text { technology }\end{array}$ & 11 & 33.8 & -22.8 \\
\hline Total & 135 & & \\
\hline
\end{tabular}


Category 1: Various Activities Should be Implemented: This category was identified by 28 female participants (44.4\%) and 28 male participants $(38.9 \%)$.

Facilitative suggestion samples for the application of the FC strategies that "various activities should be implemented" are as follows:

"Each student learns differently; for, intelligence and interests of each one is different. If activities can be diversified, we can participate in any activity we want to ensure that the applications can address to every student. We're students in geography department. To me, acquirements of the flipped classroom model can be increased through activities such as completing the blank map and classroom courses supported by outdoor field studies." (M 13)

"Documentaries, films and slide photos facilitate following current topics of lecture. If more applied the activities in which these materials are used in the lecture will be more popular." ( F 65)

"To me, each of the students in the class should prepare individual questions. If each student asks questions during lecture, it may be time consuming. In this case, students can be divided into groups, and they can prepare questions on behalf of their groups. We can prepare questions in groups on each section assigned to different groups by the lecturer so that the questions may not center on certain parts of the subject. Then, we can send our group questions to other groups and we can present answers to these questions in the class. If this learning model is administered in this way, it will be more beneficial for the students in terms of maximising their engagement." (F 70).

Category 2: The FC Online Work Should not Replace Direct Interaction: There are 24 female student teachers $(38.1 \%)$ and 26 male student teachers $(36.1 \%)$ under category 2.

Facilitative suggestion sample for the application of the FC strategies that "the FC online work should not replace direct interaction" is as follows:

"Concepts and unknown words can be defined by our lecturer, slides on the subject may be summarized and examples may be given in the first part of the lecture. Then in the second part of the lecture, class discussion can be started in which students ask and answer questions regarding the lecture materials sent beforehand via computer." (F 5)

Category 3: Quizzes Should be Applied at the end of the Lecture: There are 7 female student teachers (11.1\%) and 11 male student teachers (15.3\%) under this category.

Facilitative suggestion sample for the application of the FC strategies that "quizzes should be applied at the end of the lecture" is as follows: 


\begin{abstract}
"Dominant and competitive attitudes of some of the students in the classroom influence shy students' participation negatively. Questions can be sent back to the students via computer in short quiz formats after they are discussed in class. Student performance is graded. This application makes it easier for everyone to focus on the lecture." (F 45)
\end{abstract}

Category 4: All Students Should have Access to Technology: Category 4 was identified by 14 female participants $(6.3 \%)$ and 7 male participants $(9.7 \%)$.

Facilitative suggestion sample for the application of the FC strategies that "all students should have access to technology" is as follows:

"Sending lecture materials via computer is an application that requires internet access." (F 4)

\title{
4. DISCUSSION AND RESULTS
}

In the present study, we investigated the components to constitute of individual perceptions of university students enrolled in geography major concerning benefits of FC and to facilitate their applicability through their own observations and suggestions.

The findings obtained in this study puts forward that flipped classroom strategies have more positive effects on cognitive learning outputs and processes than traditional methods; they have positive effects on such emotional features as intrinsic motivation, anxiety level, the attitude towards the lecture and learning and create a suitable environment for the emergence of such supplementary learning outputs as participation in the lecture, independent learning, social interaction and high self-esteem.

The participants have some certain suggestions for the implementation of flipped classroom model although they think of it positively. The participants suggested designing more educational works during the implementation which are visual, naturalist and suitable for interpersonal intelligence zones and that they should make their own decision as to which activity they will participate in. Among the suggestions for activities are watching more documentary about the visual intelligence zone, completing blank maps, carrying out field research as the practice of theoretical lectures and group works regarding interpersonal intelligence zones. 
This suggestion indicates the importance of taking the intelligence zones of the target group -students- into account while planning the activities in lesson designs in which flipped classroom model is employed. It shouldn't be supposed that students can learn every subject in the geography programme by means of the activities based on verbal and mathematical intelligence such as listening, reading, answering the questions, explaining, taking notes, doing written exercises. The activities based solely on verbal and mathematical intelligence make the lesson unbearable for the students with developed kinaesthetic intelligence. Every student has a distinctive intelligence; thereby, it is inevitable that there are differences in learning styles.

Furthermore, the role of a geography teacher as the designer of the learning environment is extremely complex and hard compared to the role of transferring information by just telling the subject and leaving the classroom (Y1lmaz ve Bilgi, 2011; Zeren, 2015). The pedagogy of teaching-learning geography includes the practices of field work as well as theoretical and technical processes (Karabağ, 2007). Since the human brain is not something like a piece of sponge to be filled, students should be provided with multiple interactive experiential learning opportunities at first hand which they can add their natural inquisitiveness to, are suitable for physical movements, convenient for them to use their language and creativeness and they should be motivated (Açıkgöz, 2007, 67). Within this context, it will be a positive approach towards the process of teaching-learning geography to integrate field work opportunities into flipped classroom practices in which students can show their ability and to examine how they take advantage of these opportunities.

In addition to the fact that students have a positive attitude towards the implementation of flipped classroom strategies, which is a promising model, teachers' views, attitudes and the strategies they use in the practices will also be effective in the development of the model.

Effective questioning is an indispensable instrument used in flipped classroom practices as a cognitive strategy, for it requires effective thinking and facilitates comprehension and as a metacognitive strategy, for it is used with the aim of managing and controlling comprehension (Wong, 1985; Açıkgöz, 2007). In order for questioning 
activity to achieve its aim, and in order to assuring active thinking, the points to take into consideration are asking the questions in the right time and conveniently, and at right level as much as possible. Asking the questions untimely, pestering students with questions may cause them not to able to think; they may not learn the subject as they haven't been able to watch the discussions. As Dilon (1987) stated, asking questions while launching the discussion may hinder a deep discussion; the lesson may turn into a session in which the teacher asks questions and the students answer. Likewise, because explaining something can be easier by means of an explanatory sentence, questioning is unnecessary. Asking questions when students get confused may hinder students and stop communication. Replying to a student's question may make an impression as if the students don't have right to ask a question. The questions asked to students must be neither too hard to answer nor too easy. The questions that they can handle with some effort will motivate students.

According to the findings of the study, the suggestions for future studies can be summarised like this: More comprehensive studies can be carried out on the process-driven effects of flipped classroom practices in which distinctive learning activities are used and the attitudes of the educators towards the model.

\section{REFERENCES}

Açıkgöz, K. Ü. (2014). Aktif öğrenme (13. bask1). Ankara: Seçkin Yayıncilik.

Baker, J. W. (2000, April). The "Classroom Flip": Using web course management tools to become the guide by the side. In J. A. Chambers (Ed.), Paper presented at the 11th International Conference on College Teaching and Learning (pp. 9-17). Jacksonville: Florida Community College.

Bergmann, J. and Sams, A. (2012). Flip your classroom: Reach every student in every class every day. Washington, DC: International Society for Technology in Education.

Bergman, J. and Sams, A. (2014). Flipped learning: Maximizing face time. $T+D, 68(2), 28-31$. 
Bishop, J. L. and Verleger, M. A. (2013, June). "The Flipped Classroom: A Survey of the Research", 120 th American Society of Engineering Education Annual Conference \& Exposition (pp. 23-26), Atlanta, Georgia, United States.

Brown, A. F. (2012). A phenomenological study of undergraduate instructors using the inverted or flipped classroom model. Unpublished doctoral dissertation, Pepperdine University, Malibu.

Bruff, D. (2009). Teaching with Classroom Response Systems. San Francisco: Jossey-Bass.

Büyüköztürk, Ş. (2005). Sosyal bilimler için veri analizi el kitabı (20. Bask1). Ankara: PegemA Yayıncılık.

Caine, R. N. and Caine, G. (1991). Making connections: Teaching and the human brain. USA: ASCD Yayını.

Collins, A. (2006). Cognitive apprenticeship. In R. K. Sawyer (Ed.) The Cambridge handbook of the learning sciences (pp. 47-60). Hillsdale, NJ: Erlbaum.

Conner, N. W., Stripling, C. T., Blythe, J. M., Roberts, T. G. and Stedman, N. L. P. (2014). Flipping an Agricultural Education Teaching Methods Course. Journal of Agricultural Education, 55(2), 66-78.

Demiralay, R. ve Karataş, S. (2014). Evde Ders Okulda Ödev Modeli. Eğitim ve Ögrretim Araştırmaları Dergisi, 3(3), 333-340.

Dillon, J. T. (1984). Reseach on questioning and discussion. Educational Leadership, 42, 50-57.

Frederickson, N., Reed, P. and Clifford, V. (2005). Evaluating websupported learning versus lecture-based teaching: Quantitative and qualitative perspectives. Higher Education, 50, 645-664.

Fulton, K. P. (2012). Upside down and inside out: Flip your classroom to improve student learning. Learning \& Leading with Technology, 39(8), 12-17. 
Fulton, K. P. ( 2013). Byron's flipped classrooms. Education Digest, 79(1), 22-26.

Gannod, G. C., Burge, J. E. and Helmick, M. T. (2008, May). "Using the inverted classroom to teach software engineering" Proceedings of the $30^{\text {th }}$ international conference on Software engineering (pp. 10-18), Leipzig, Germany.

Gaughan, J. E. (2014). The flipped classroom in world history. History Teacher, 47(2), 221-244.

Goodwin, B. and Miller, K. (2013). Evidence on flipped classrooms is still coming in. Educational Leadership, 70 (6), 78-80.

Handwerker, S. M. (2012). Transforming nursing education: A review of current curricular practices in relation to Benner's latest work. Int J Nurs Educ Scholarsh, 9 (1), 1-16.

Hawks, S. J. (2014). The Flipped Classroom: Now or Never ? Education News, 82(4), 264-269.

Herreid, C. F. and Schiller, N. A. (2013). Case studies and the flipped classroom. Journal of College Science Teaching, 42(5), 6266.

Karabağ, S. ve Şahin, S. (2007). Kuram ve Uygulamada Coğrafya Eğitimi. Ankara: Seçkin Yayıncılık.

King, A. (1993). From sage on the stage to guide on the side. College Teaching, 41(1), 30-35.

La Fee, S. (2013). Flipped Learning. Education Digest, 79(3), 13-18.

Lage, M. J., Platt, G. J. and Treglia, M. (2000). Inverting the classroom: A gateway to creating an inclusive learning environment. Journal of Economic Education, 31, 30-43.

Lancaster, S. J. (2013). The flipped lecture. New Directions in the Teaching of Physical Sciences 9, 28-32.

Luntley, M. (2009). Understanding expertise. Journal of Applied Philosophy, 26(4), 356-370.

McKnight, P., McKnight, K. and Arfstrom, K. (2013). A review of flipped learning. Flipped Learning Network. 
Milman, N. (2012). The flipped classroom strategy: What is it and how can it be used? Distance Learning, 9(3), 85-87.

Mull, B. (2012, March 29). Flipped learning: A response to five common critisms. November Learning. http://novemberlearning.com/resources/articles/flippedlearnin g-a-response-to-five-common-criticisms-article.

Papadapulos, C. and Roman, A. S. (2010). Implementing an inverted classroom model in engineering statistics: Initial results. American Society for Engineering Statistics. Preceedings of the $40^{\text {th }}$ ASEE/IEEE Frontiers in Education Conference, Washington DC.

Pierce, R. and Fox, J. (2012). Vodcasts and active-learning exercises in a "flipped classroom" model of a renal pharmacotheraphy module. American Journal of Pharmaceutical Education, 76(10), 1-5.

Roehl, A., Reddy, A. L. and Shannon, G. J. (2013). The flipped classroom: An opportunity to engage millennial students through active learning strategies. Journal of Family \& Consumer Science, 105(2), 44-49.

Sadaghiani, H. R. (2012). Online prelectures: An alternative to textbook reading assignments. The Physics Teacher, 50(5), 301-303.

Sever, G. (2014). Bireysel çalgı keman derslerinde çevrilmiş öğrenme modelinin uygulanması. Ĕgitimde Nitel Araştırmalar Dergisi - Journal of Qualitative Research in Education, 2(2), 27-42.

Steed, A. (2012). The flipped classroom. Teaching Business \& Economics, 16(3), 9-11.

Strayer, J. (2012). How learning in an inverted classroom influences cooperation, innovation and task orientation. Learning Environments Research, 15,171-193.

Svinicki, M. D. (2004). Authentic assessment: Testing in reality. New Directions for Teaching and Learning, 100, 23-29.

Tucker, B. (2012). The flipped classroom. Teaching Business \& Economics, 16(3), 9-11. 
Vaughan, M. (2014). Flipping the Learning: An Investigation into the use of the Flipped Classroom Model in an Introductory Teaching Course. Education Research and Perspectives, 41, 25-41.

Wallace, M. L., Walker, J. D., Braseby, A. M. and Sweet, M. S. (2014). "Now, What Happens During Class?" Using Team-Based Learning to Optimize the Role of Expertise Within the Flipped Classroom. Journal on Excellence in College Teaching, 25(3\&4), 253-273.

Wilson, M. and Gerber, L. E. (2008). How generational theory can improve teaching: Strategies for working with the "millenials." Currents in Teaching and Learning, 1(1), 29-44.

Yeung, K. and O’Malley, P. J. (2014). Making “The Flip” Work: Barriers to and Implementation Strategies for Introducing Flipped Teaching Methods into Traditional Higher Education Courses. New Directions in the Teaching of Physical Sciences, 10, 59-63.

Yıldırım, A. ve Şimşek, H. (2013). Sosyal bilimlerde nitel araştırma yöntemleri (9. Baskı). Ankara: Seçkin Yayıncılık.

Yılmaz, C.ve Bilgi, M. G. (2011). Aday Öğretmenlerin Coğrafya Arazi Çalışmalarına Bakışı. Kuram ve Uygulamada Eğitim Bilimleri / Educational Sciences: Theory and Practice 11(2), 961-983.

Zappe, S., Leicht, R., Messner, J., Litzinger, T. and Lee, H. (2009). "Flipping" the classroom to explore active learning in a large undergraduate course. Proceedings of the 2009 American Society for Engineering Education Annual Conference and Exhibition.

Zeren, M. G. (2015). Üniversite Öğrencilerinin Gözü ile Coğrafya Eğitimcisi: Bir Olgubilim Araştırması. Doğu Coğrafya Dergisi 33(20), 189-208. 


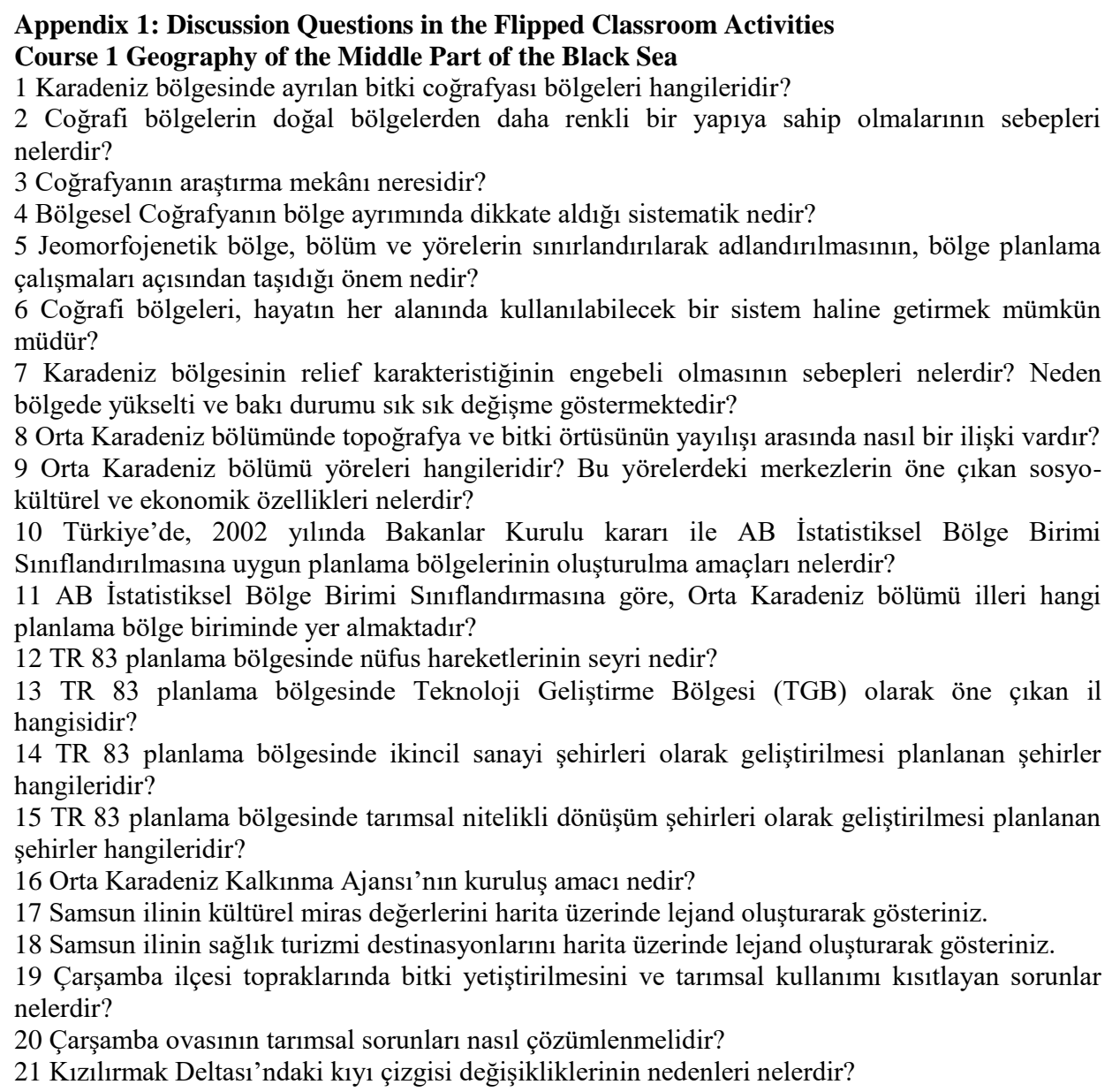

Course 2 Climate Changes and Their Environmental Effects

1 Kuvvetlenmiș sera etkisi hakkında ne düşünüyorsunuz?

2 Küresel ısınma ile mücadelede toplumların cevaplaması gereken en önemli soru ne olabilir?

3 İklimbilimde "pozitif geri bildirimler" adı altında toplanan kâbus senaryoları nelerdir?

4 Kış mevsiminin daha kısa, daha 1lıman geçtiği permafrost bölgelerinde günümüzde hangi riskler ortaya çıkmaktadır?

5 Bütün buzlar erirse, yaşanması olası felaketler dünyamızı yeniden nasıl biçimlendirir?

a. Deniz seviyesine ilişkin en kötü felaket ne olur?

b. Su kaynaklarına ilişkin tehditler ne olur?

c. Fauna ve flora açısından tehditler nelerdir?

d. Okyanus akıntıları açısından tehditler nelerdir?

6. Botswana kırsalında yaşayan bir aile ile Hindistan'da yaşayan bir ailenin küresel ayak izini karşılaştırınız.

7. Metan iklim bombası mıdır? Geleceğin yakıtı olarak mı görülmektedir? 
THE FLIPPED GEOGRAPHY LECTURE

8. Fracking olarak bilinen hidrolik çatlatma yöntemi ile kaya gazı sondajlarının çevresel etkileri nelerdir?

9. İklim değişmelerinin olası etkilerinin hesaplandığı iklim modellerinden çıkan sonuçlar nelerdir?

10. İklim değişikliğinin ve özellikle deniz düzeylerindeki artışın küresel maliyeti nedir? /

Türkiye'ye mal olan ekonomik bedeli nedir?

11. İklim değişikliğine paralel artış göstereceği öngörülen hastalıklar nelerdir?

12. 2050 yılına gelindiğinde beslenmesi gereken insan sayısına 2 milyar kişi daha eklenecek. 9

milyar kişiye yetecek gıdayı nereden bulacağız?

13. Konvansiyonel tarım veya organik, küçük ölçekli yerel üretici arasında tercih yapmak durumunda mıyız? Bir üçüncü yol yok mudur?

14. Konvansiyonel tarımı destekleyenlerin haklılık payı nedir?

15. Yerel ve organik tarımı savunanların haklılık payı nedir?

16. Bilim, 1970'lerde yaşanan gıda krizini yeşil devrimle önlemiş; 1990'lara kadar Asya'daki çeltik ve buğday verimliliği ikiye katlanmıştır. Yeni bir yeşil devrim, dünyayı gıda krizinden kurtarabilir mi?

17. Tarımdaki sorunların tek başına biyoteknoloji tarafindan çözülmesi mümkün müdür?

18. Büyük şirketlerin Afrika kıtasında kapış kapış toprak almasının nedeni nedir?

19. Afrika'da toprağa hücumun ardında yatan fikir, dünyayı doyurma gibi asil bir düşünce midir?

20. 1960-2000 yılları arasında, tahıl üretimini iki katın üzerinde artıran yeşil devrimin yarattığı gübre, sulama ve rekoltesi yüksek tohum karışımının Afrika kıtasında kök salamamasının nedenleri nelerdir?

21. Afrika'da desteklenen dış üretici modelinin büyük ölçekli üretimle kıyaslandığında avantajlı yönleri nelerdir?

22. ABD'de açlığın değişen yüzünün ve değişen adresinin ortaya çıkardığı fotoğrafi değerlendiriniz.

\section{Course 3 Rural Potential of Turkey}

1 Kır ve köy kavramları farklı kavramlar mıdır?

2 Şehir ve kır yerleşmesi ayrımında sadece nüfus miktarı ölçütünü dikkate almak yeterli midir?

3 Türkiye'de insanları köyden şehre göçe iten nedenler hangileridir?

4 Türkiye köylerindeki ekonomik uğraşı düzenleri nelerdir

5 Küçük ölçekli tarım üreticilerinin Türkiye'deki sorunları nelerdir?

6 Türkiye tarımla kalkınabilir mi?

7 Türkiye'deki tarım arazilerinin bölgesel dağılış özellikleri nelerdir?

8 Türkiye'de kırsal yerleşme deseninin genel karakteristiği nedir?

9 Türkiye'den ve dünyadan ekolojik yerleşim girişimlerine örnek verebilir misiniz?

10 Tarım topraklarının stratejik açıdan taşıdığı önemi değerlendiriniz.

11 Türkiye tarım sektöründe geliştirilmesi hedeflenen stratejik alanlar hangileridir?

12 Miras yoluyla bölünen topraklarla ilgili yapılan kanuni düzenlemenin kapsamı nedir?

13 Türkiye tarım sektörünün tarımsal üretim ve arz güvenliği alanındaki güçlü yönleri nelerdir?

14 Türkiye tarım sektörünün tarımsal üretim ve arz güvenliği alanındaki zayıf yönleri nelerdir?

15 Türkiye tarım sektöründe tarımsal üretim ve arz güvenliği alanındaki firsatlar nelerdir?

16 Türkiye tarım sektöründe tarımsal üretim ve arz güvenliği alanındaki tehditler nelerdir?

17 Kuraklıkla mücadelede Türkiye'de hayata geçirilen uygulamalar nelerdir?

18 Buğdayın hafizasını tazelemek ne anlama gelmektedir?

19 Yerel tohumların yaygınlaşması için hayata geçirilen projeler nelerdir?

202014 yılının Aile Çiftçiliği yılı ilan edilmesinin sebebi nedir? 
21 Bugün özlemi çekilen Anadolu'nun yerel çeşitlerinin (atalık tohumlar) bilim insanları için taşıdığı değer nedir?

22 Buğdayın Anadolu insanı için taşıdığı önem nedir?

23 Türkiye'de Yerel Buğday Çeşitlerinin Envanterinin Çıkarılması Projesi'nin amacı nedir?

24 Yerel çeşitlerin gen bankasında korunması yeterli midir?

25 Yerel buğday çeşitlerinin ekiminin devamlılığında coğrafi işaretleme sisteminin taşıdığı önem nedir?

26 Buğday Ekolojik Yaşamı Destekleme Derneği’nin yürüttüğü Tohum Takas Ağı Projesi’nin amac1 nedir?

27 Bal nasil elde edilir?

28 Doğal bal nedir?

29 Türkiye'de bal elde edilen bölgeler hangileridir?

30 Tarım ilaçlarının fazla dozda kullanılması arılarda nasıl bir etki yaratmaktadır?

31 Arı ölümlerinde iklim değişmelerinin etkisi olduğunu düşünüyor musunuz?

\section{Course 4 Environmental Management}

1 Sakin şehirlerin sürdürülebilir bir çevreye katkıları nelerdir?

2 Kirlilik kontrolü ve sürdürülebilir üretim yaklaşımları arasında fark var mıdır?

3 Türkiye'den ve dünyadan sürdürülebilir üretimin geliştirilmesine yönelik projelere örnek verebilir misiniz?

4 Permakültürel yaklaşımların çevresel Kuznets eğrisi olarak adlandırılan söylemin karşı cephesinde yer almasının sebebi nedir?

5 Sanayide enerji verimliliği ne anlama gelmektedir?

6 Plastik kullanımının en iyi yönetimi nedir?

7 Taş devri, demir devri ve plastik devrinin ardından bugün hayatımızı tamamen değiştiren hangi devrim gerçekleşmektedir?

8 Hiçbir şeyin çöpe atılmadığı bir dönem (sıfır atık dönemi) mümkün olabilir mi?

9 NY Belediyesi Çevre Koruma Birimi tarafından 2014 yılında hayata geçirilen Sünger Parkı projesinin işleyiş mekanizmasını açıklayınız.

10 Palmiye yağı üretiminin çevresel etkileri nelerdir?

11 Petrol sızıntılarının çevresel etkileri nelerdir?

12 Köpekbalığı yüzgeci ticareti sürdürülebilir bir faaliyet midir?

13 Kuraklıkla mücadelede hayata geçirilen uygulamaları örneklendiriniz.

14 Yeşil beslenme ne anlama gelmektedir? Küresel gıda izini -yediğimiz ürünlerin karbon ayak izini- hafifletebilir mi?

15 Gıda bankası kurma fikri nasıl ortaya çıkmıştır?

16 Pasif ev nedir?

17 İklimi koruyan ve yapılarda enerji maliyetlerini düşüren çözümleri örneklendiriniz.

\section{Extended Abstract}

Flipped Classroom, literatürde 2000'li yıllardan itibaren yer almakla birlikte, son birkaç y1ldır ilgi gören bir öğrenme modelidir.

Flipped Classroom modelinin son yıllarda popülaritesinin artması, geleneksel öğretimin çağın gerektirdiği insan kaynaklarının yetiştirilmesinde etkili olamayışına gösterilen bir reaksiyondur. Çağın gerektirdiği amaçlar konulsa dahi, bu amaçları geleneksel yöntemlerle gerçekleştirmek imkânsızdır. Geleneksel yöntemlerde öğrencileri düşündüren ve araştırmaya teşvik eden etkinlikler sunulmadığı; bilgiyi kullanma, problem çözme ve bilgiyi yeniden yapılandırma firsatları verilmediği için, öğrenciler ezberledikleri yüzeysel bilgilerle mezun olmaktadır. Etkili düşünme, problem çözme ve araştırma becerilerinden yoksun olan bireyler ileriki yaşamlarında karmaşık bir durumla karşılaşınca uygun çözümler üretememektedir. 
THE FLIPPED GEOGRAPHY LECTURE

Her şeyin öğretmen tarafından belirlendiği, sunulduğu ve kontrol edildiği sınıflarda kullanılan geleneksel öğretim yöntemlerinin, öğrencilerin doğal olarak sahip olduğu bilme-anlama isteğini körelttiği, onları edilginleştirdiği ve düşünmelerini engellediği yönündeki eleştiriler, flipped classroom modelinin temelinde yer alan; bilginin hazır olarak aktarılmaması, öğrencilerin kendi öğrenme sürecinin sorumluluğunu taşıması, öğrencilerin kendi bilgi edinme çabalarını kendilerinin başlatması ve yönlendirmesi gibi uygulamaların hayata geçirilmesine ivme kazandırmıştır.

Flipped classroom, öğrencilerin, öğretmen tarafından organize edilerek sosyal ağ platformunda paylaşılan ders içeriğini inceleyip, videolar izleyerek, makaleler okuyarak ve paylaşılan içeriğe yönelik kısa sınav sorularının çözümleri üzerinde önceki bilgileri ışı̆̆ında düșünerek, içeriğin derinlemesine tartıșılacağı sınıfa hazırlıklı geleceği bir modeldir. Modelin gelişimi fikri, ders için hazırlanan materyallerin elektronik ortama taşınmasının gerekliliğ vurgulanarak açıklanmaktadır. Model uygulandığında, öğretmenin ders içeriğinin sunumu için harcayacağı zaman, zenginleştirilmiş öğrenme etkinlikleri için kullanılabilmektedir. Model, uygulanışı bakımından elektronik öğrenme platformlarının sunduğu esnekliği, sınıf ortamının sunduğu sosyal etkileşimle birleştirerek, yüz yüze eğitimin kalitesini yükseltmektedir. Derse ön hazırlık yaparak gelen öğrenciler öğretmenin tasarladığı sınıf içi etkinliklere aktif olarak katılmaktadır. Öğretmen, öğrencilerin ders için paylaşılan içeriğe hazırlanıp hazırlanmadığını tespit ederek derse başlangıç yapmakta, ardından öğrencilerin konuya ilişkin düşüncelerini paylaşmasını, sorular sormasını, tartışmasını, değerlendirmeler yapmasını sağlamakta ve paylaşılan içerikle ilgili öğrenilenlerin uygulanabileceği etkinlikler tasarlamaktadır.

$\mathrm{Bu}$ araștırma, üniversite coğrafya bölümü öğrencilerinin flipped classroom stratejilerinin kazanımlarına ve uygulanabilirliğinin kolaylaştırılmasına ilișkin düşüncelerini, kendi gözlem ve önerilerinden hareketle inceleme amacına yönelik olarak gerçekleştirilmiştir. Bu genel amaç çerçevesinde, aşağıdaki sorulara cevap aranmıștır: (1) Üniversite coğrafya bölümü öğrencilerine göre, katıldıkları derslerde kullanılan FC stratejilerinin önemli kazanımları nelerdir? (2) Üniversite coğrafya bölümü öğrencilerinin, katıldıkları derslerde kullanılan FC stratejilerinin uygulanmasını kolaylaştırıcı önerileri nelerdir? (3) Üniversite coğrafya bölümü öğrencilerinin, FC stratejilerinin önemli kazanımlarına ilişkin gözlemleri ve önerileri, ortak özellikler bakımından hangi kavramsal kategoriler altında toplanabilir? (4) Öne çıkan kavramsal kategoriler, üniversite coğrafya bölümü öğrencilerinin cinsiyeti bakımından farklılık göstermekte midir? Araştırmaya 63 'ü kız (\%47) ve 72'si erkek (\%53) olmak üzere toplam 135 üniversite coğrafya bölümü öğrencisi katılmıştır. Araştırma sonucunda elde edilen veriler hem nitel (içerik analizi) hem de nicel (Chi-square) veri çözümleme teknikleri kullanılarak analiz edilmiştir. Araştırmanın bulgularına göre: (1) Üniversite coğrafya bölümü öğrencilerinin flipped classroom stratejilerinin önemli kazanımlarına ilișkin gözlemleri, bu gözlemlerin ortak özellikleri dikkate alınarak sekiz kavramsal kategori altında toplanmıştır. (2) Üniversite coğrafya bölümü öğrencilerinin FC stratejilerinin uygulanmasını kolaylaştırıcı önerileri, ortak özellikleri bakımından dört kategori altında toplanmıştır. (3) Katılımcıların öncelikli gözlem ve önerileri bir bütün olarak değerlendirildiğinde, üniversite coğrafya bölümü öğrencilerinin cinsiyeti bakımından önemli derecede farklılık görülmemiștir.

$\mathrm{Bu}$ araştırmada elde edilen bulgular, flipped classroom stratejilerinin bilişsel öğrenme ürünleri ve süreçleri üzerinde, geleneksel yöntemlere göre daha olumlu etkiler bıraktığını, içsel motivasyon, kaygı düzeyi, derse ve öğrenmeye yönelik tutum gibi duyuşsal özellikler üzerinde olumlu etkilerinin bulunduğunu ve derse katılım, bağımsız öğrenme, sosyal etkileşim, eleştirel düşünme, yüksek benlik saygısı gibi destekleyici öğrenme ürünlerinin oluşmasına elverişli bir ortam yarattı̆gını ortaya koymaktadır.

Flipped classroom modeli hakkında olumlu bakıs açısına sahip olmakla birlikte, katılımcıların, modelin uygulanmasının kolaylaştırılmasına ilişkin birtakım önerileri bulunmaktadır. Katılımcılar, uygulamalar gerçekleştirilirken derslerde özellikle görsel, doğalcı ve 
kişilerarası zekâ alanlarına uygun daha fazla öğretimsel iş tasarlanmasını ve hangi etkinliğe katılacaklarına kendilerinin karar vermesini önermiștir. Etkinlik önerileri arasında, görsel zekâ alanıyla ilgili daha fazla belgesel izlenmesi, haritaların dillendirilmesi, doğalcı zekâ alanıyla ilgili teorik derslerin pratiği niteliğinde saha araştırmalarına çıkılması ve kişilerarası zekâ alanıyla ilgili grup çalışmaları yapılması bulunmaktadır.

$\mathrm{Bu}$ öneri, flipped classroom modelinin kullanıldı̆̆ 1 ders tasarımlarında etkinlikler planlanırken, hedef kitleyi oluşturan öğrencilerin zekâ alanlarının göz önünde bulundurulmasının önemini ortaya koymaktadır. Öğrencilerin, coğrafya programındaki her konuyu dinleme, okuma, soruları cevaplama, açıklama, not alma, yazılı alıştırmaları yapma gibi sözel ve matematiksel zekâlara dayalı etkinlikler ile öğrenebileceği düşünülmemelidir. Salt sözel ve matematiksel zekâlara dayalı etkinlikler, bedensel-hareketsel zekâları gelişmiş öğrenciler için dersleri çekilmez hale getirmektedir. Her öğrencinin zihin yapısı farklıdır; bu bağlamda öğrenme biçimlerinde farklılıklar olması kaçınılmazdır.

Ayrıca, öğrenme ortamını tasarlayıcı olarak coğrafya eğitimcisinin rolü, anlatıp sınıftan çıkılan bilgi aktarma rolüyle karşılaştırıldığında oldukça karmaşık ve zor bir roldür. Coğrafya ögrrenme-öğretme pedagojisi, teorik ve teknik aşamaların yanı sıra arazi çalışmaları uygulamalarını da içermektedir. İnsan beyni sünger gibi doldurulacak bir obje olmadığından dolayı sınıf içinde kâğıt kalemle yapılan çalışmaların ötesinde, öğrencilere, doğal meraklarını katabilecekleri, fiziksel harekete uygun, dili ve yaratıcılıklarını kullanmaya elverişli, ilk elden çoklu etkileşimli yaşantısal öğrenme firsatları sunulmalı ve öğrencilerin özdenetimi özendirilmelidir. $\mathrm{Bu}$ bağlamda, flipped classroom uygulamalarına, öğrencilerin doğalcı zekâ alanında kendilerini gösterebilecekleri saha araştırması firsatları entegre edilerek, onların bu firsatları nasıl kullandıklarına bakmak, coğrafya öğrenme-öğretme sürecini olumlu yönde destekleyen bir yaklaşım olacaktır.

Öğrencilerin, gelecek için umut vaat eden flipped classroom modelinin uygulanmasına ilişkin olumlu bakış açısına sahip olmasının yanı sıra, modelin geliştilmesinde alan eğitimcilerinin bakış açısı, tutumu ve uygulamalarda kullanacakları stratejiler de etkili olacaktır. Flipped classroom uygulamalarında etkili soru sorma, etkili düşünmeyi gerektirdiği ve kavramayı kolaylaştırdığı için, bilişsel strateji olarak; kavramayı yönetmek ve kontrol etmek amaciyla kullanıldığı için ise bilişüstü strateji olarak kullanılan vazgeçilmez bir araçtır. Soru sorma etkinliğinin amacına ulaşabilmesi ve aktif düşünmenin sağlanabilmesi için dikkat edilmesi gereken, soruların zamanında, uygun biçimde sorulması ve mümkün olduğu kadar düzeyli tutulmasidir.

Araştırmanın bulgularına dayalı olarak, ileriye dönük araştırmalar için geliştirilen öneriler şöyle özetlenebilir: Farklı öğrenme aktivitelerinin kullanıldığı flipped classroom uygulamalarının süreç odaklı etkileri ve alan eğitimcilerinin modele yönelik tutumlarına ilişkin daha kapsamlı çalışmalar yapılabileceği düşünülmektedir. 